\title{
Fifty Years of Traditional Gender Roles on Mexican Textbooks for Elementary School
}

\author{
Mayra Margarito Gaspar, Silvia Quezada Camberos
}

Department of Letters, Guadalajara University, Guadalajara, México

Email address:

mayram_g@hotmail.com (M. M. Gaspar)

\section{To cite this article:}

Mayra Margarito Gaspar, Silvia Quezada Camberos. Fifty Years of traditional Gender Roles on Mexican Textbooks for Elementary School. Advances in Sciences and Humanities. Vol. 5, No. 1, 2019, pp. 1-9. doi: 10.11648/j.ash.20190501.11

Received: November 13, 2018; Accepted: November 29, 2018; Published: January 21, 2019

\begin{abstract}
This research observes the construction of gender roles throughout the action of basic education school, taking as a guiding axis how textbooks depict the feminine and masculine figures. The Comisión Nacional de Libros de Texto Gratuitos (CONALITEG - National Commission of Free Textbooks) distributes the official textbooks for basic education to all public or private Mexican schools. This government agency is also responsible for designing and editing books and printed materials to complement the programs and educational reforms to be implemented. The volumes intended for primary school students constitute the object of this research, since they have become the main teaching tool. The corpus consists of editions from 1960 to 2009; these books correspond to three educational reforms. The use of texts of different periods allowed to establish a comparison between the men's and women's functions in fifty years. The theoretical-methodological approach of this paper is based on the Barthes' iconographic proposal. This author explains the social nature of speech figures, analyzing the denoted and connoted messages of visual texts. Following this perspective, images of different decades were reviewed to observe the dialogue they establish and through which two gender figures are constructed: the female motherhood and the male productiveness.
\end{abstract}

Keywords: Gender Roles, Textbooks, Image, Identity, Discourse

\section{Introduction}

Textbooks are the main devices for teaching in basic education. Educative practices focused on these materials are common to find in elementary school's classrooms. Necessary information of the thematic contents is located on their pages; the assignments done in the courses are the tasks proposed on these volumes. Although they cannot determine the work dynamics in the classroom by themselves, they have been constituted in guides and support for the planning of didactic strategies and activities. In Mexico, government is in charge for the free edition and distribution of basic education textbooks; for this reason, they have become official materials that students receive and study compulsorily.

Formal education collaborates in shaping an image of the individuals, of their peers, of their space and of their role in society. Giddens [1] asserts that the perception of the being is socially constituted. Therefore, the background and the institutions where a person interacts are decisive elements for the conformation of identity. Hence, textbooks for the elementary school have become an opportunity for integration and for the construction of an official image of gender roles. This work aims to observe what is the official construction of femininity and masculinity, by analyzing the illustrations that have been presented to first and second grade students on their textbooks for the subject of Spanish.

Authors, who have studied textbooks in Mexico from a diachronic approach [2-4] differentiate three generations of official textbooks for elementary school in the first fifty years of the CONALITEG. First one includes the volumes from 1960 to 1971 (although some titles continued to be published until 1974, due to the delay of the edition that corresponded to the new educational reform). The second one comprises texts from 1972 to 1992 (considering that, just as happened in the transition from the first to the second generation, not all the books were changed at the same time). The third one encompasses the titles that began to be published in 1993 and which, depending on the subject, continued to be used until 2009, 2010 and 2011.

This study analyzes the Spanish textbooks for the two first 
grades of all the editions of these three generations. These volumes were chosen in special because the books for the first grades have the greatest number of images. In addition, the subject of Spanish has the highest workload in basic education. For these reasons, this work seeks to review men's and women's roles in these educational materials, establishing the female motherhood and the male productiveness as the two principal gender figures.

\section{Theoretical-Methodological Approach}

Historically, textbooks have been a key component to guide the track of education. Teachers use bibliographic sources for the search of information, examples and strategies to achieve the educational purposes. For this reason, the distribution of textbooks correlated with the purposes of the curriculum is always considered an important part of materials to be delivered at the beginning of every school year [5]. In the case of Mexico, materials for elementary schools are distributed by a government agency; for this reason, textbooks have acquired an official character that has made them basic tools for equal and free education. Due to its importance for current education, free textbooks also promote a State control over formal education; this phenomenon constitutes what is called "legitimated education monopoly" [6].

The official educational materials are a main part of the apparatus to achieve the instruction required by a social system. Textbooks establish a training guideline for working with schoolchildren. They privilege certain information and cognitive skills, validating certain values, behaviors, customs and traditions. Due to their formative function and their importance for basic education, this work studies textbooks' images as instruments for the construction of cultural knowledge, such as the gender roles instituted for boys and girls.

Iconographic language can expose details quickly and clearly. While written descriptions of qualities, processes, places, objects or characters can be long and imprecise, an image can show a complete message in a single picture [7]. Because the accuracy of its content, the visual text is often associated with the "reality" or the "truth". Sartori [8] states that the visible imprisons people in the visible, that is, what people see is what exists.

Gombrich [9] notes that producing an image requires selecting the elements that the author considers relevant. For this reason, even though there is an intention to convey visual information in a reliable and objective manner, the iconographic text is always a reenactment of the referent. Thus, the image is a construct, a cut that is not the reality, not even a part of it; it is an elaboration from a certain perspective and intentionality.

Considering this, Barthes [10] has proposed to ponder two types of messages in iconographic texts: "a denoted message, which is the analogon itself, and a connoted message, which is the manner in which the society to a certain extent communicates what it thinks of it". The denoted message corresponds to the anecdote; it is what is shown as such. The connoted message is historical and cultural; it depends on the knowledge that a subject has socially learned.

The analysis of the textbooks illustrations includes the two types of messages, denoted and connoted. First, this study focusses on observing how the feminine and the masculine are represented in an anecdotal level; then, it elaborates on how these ritualized interactions ${ }^{1}$ institute gender roles at a symbolic and ideological level [11-12]. In this way, the analysis addresses two levels of reading: the "analyticalstructural" and the "socio-historical". The analyticalstructural reading aims to identify the issues that each image addresses and to recognize thematic patterns. Subsequently, the socio-historical analysis allows to recognize the male and female figures and to establish the differences between them.

Barthes [13] defines the figure as a fragment of speech that has a specific meaning; so, through the analysis of all figures, the full meaning of a text is revealed. Corona [12] retakes and redefines this concept as significant minimum particles through which the themes, that display the meaning of the text, are established. In this paper, the figure is understood similarly to Corona's perspective, that is, as discursive elements that have a symbolic meaning through which can be found indicators of the continuities and transformations in the constructions of the male and female representations. Below, this analysis observes how the gender roles have been consolidated through the images on official Mexican textbooks.

\section{Results and Discussion}

Images configure meanings that allow developing a social elaboration of reality [14], so its function is not only the transmission but also the conformation of a point of view. Hence, reviewing the illustrations of textbooks is necessary, not only as educational tools but as instruments for the construction of male and female figures. Gender roles from educational discourses are elaborated through homogenizing stereotypes that exclude the plurality of individuals' interpretations and their relationships [15].

Illustrations on didactic materials have often used wellknown things for students, such as animals, toys, children, families. In fact, family images have become an ideal example to introduce the students to the tasks of their condition as boys or girls. Although gender roles expressed on textbooks' pages correspond to the traditional feminine and masculine functions, the illustrations do not show just one single representation of man and woman. Indeed, male and female roles are introduced through a reconstruction of the mythical figures of the Mexican father and mother, as discussed below.

1 The "ritualized interaction" is a concept that refers to everyday scenes shown on advertising texts that, due to their constant repetition, have become ideal expressions of a gender discourse [11] or an otherness discourse [12]. 


\subsection{The Working Father}

Mexico's origin is commonly located during the period known as the Conquest, this is, in the encounter between the Indian and the Spanish, the two miscegenation progenitors. In this mythical union, several authors [16-18] have observed the emergence of very precise gender roles. Feminine images always refer to the primary woman, to the mother; on the contrary, the man does not necessarily represent the father. This substantial difference in gender issues arises because of the violence that the conquest supposed.

The father is an absent figure associated with the conqueror who subjugates and leaves; as opposed, the woman becomes a subdued and dual character. The feminine figure is the indigenous mother, suffered and raped (represented by the Malinche), as well as the virgin and protective mother (represented by the Virgin Guadalupe). On the textbooks' pages, the figure of the father was reelaborated into an ennobled prototype of a family man.

In opposition to the mythical patriarch, the father of these images is a fundamental presence for the functioning home. The role as the head of the family is not only to provide material things and protect the house, but also, taking care of the children. Despite the contribution in activities to fix the house and participate in the children's education, the actions of men do not exceed the limits of a socially accepted male function (see Figure 1). For this reason, the father collaborates in the house doing manual tasks that require the tools and the strength of a masculine figure; also, when playing with the kids, the father only chooses games suitable for men (see Figure 2).

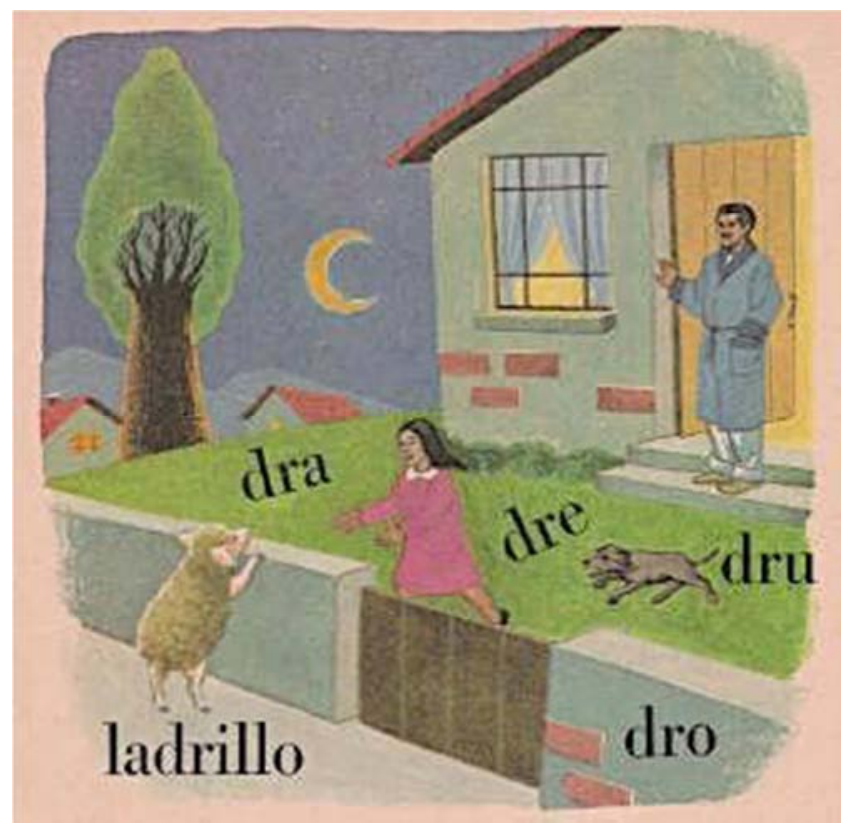

Figure 1. My first-grade textbook, 1963, p. 66.

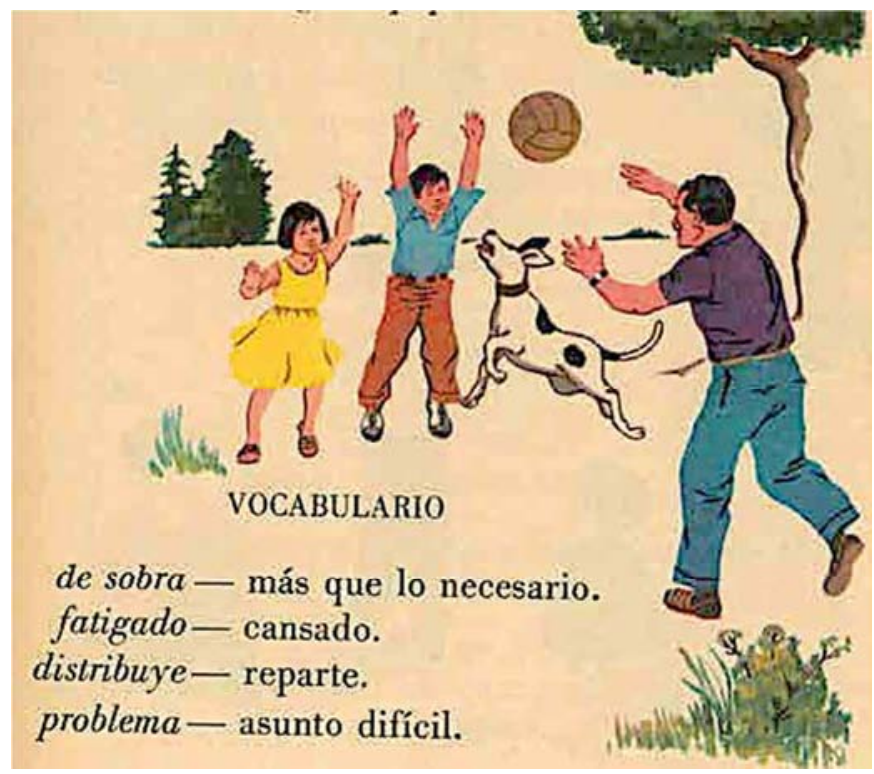

Figure 2. My first-grade textbook, 1963, p. 33.

Although textbooks try to respect masculine roles as much as possible, these educational materials show a committed father taking care of the daughters and sons, as well as helping inside the house. For this reason, since the 1960 editions, it can be seen a distancing from the macho image, which was observed in numerous previous discourses, such as movies, songs, advertising, novels.

Fernández states that since the sixties, but even more since the seventies, there has been a continuous and growing attack on machismo through different means and in several sectors, maybe in multiple or in the majority of them. In this effort, the women, naturally the most interested and affected, have had an indisputable and effective part; but not only them. The myth of the Mexican macho has been transformed and has entered (permanently?) in the field of discrediting, though it seems to be merely a statement in many cases $[19]^{2}$.

The father is a fundamental member of the family; nevertheless, it should be noted that the male role corresponds not only to the father, but also to the worker. In this way, textbooks represent two sides of the masculine figure: one related with the domestic environment (as a family man); and another one linked with the professional world (as a career man).

Despite this dichotomy, it is necessary to emphasize that there is a connection between the father and the worker: the father, as the provider of the family, must have a job to obtain the resources to support the wife and children. This portrait fits the social vision of men as productive members of the community and leads boys to start working at a younger age than girls [20].

2 Desde los años sesenta, pero más aún desde los setenta, se ha dado un continuo y creciente embate al machismo a través de distintos medios y en varios, que no múltiples ni mayoritarios, sectores. En él han tenido papel indiscutible y efectivo, naturalmente las más interesadas y afectadas, las mujeres; pero no sólo ellas. El mito del macho mexicano ha tenido su transformación $\mathrm{y}$ ha ingresado (¿de manera definitiva?) en el terreno del desprestigio, así éste parezca en muchos casos meramente declarativo [19]. 
Male jobs are defined by the place of residence. The occupation of the inhabitants of the rural area requires the use of force and manual labor; whether they work as farmers, craftsmen or exercising a trade (see Figures 4 and 5). On the other hand, the employment of the citizens implies more intellectuality and / or ability; they usually work as professionals, technicians or providers of a service, or as employees in a company, factory or institution (see Figures 3 and 6).

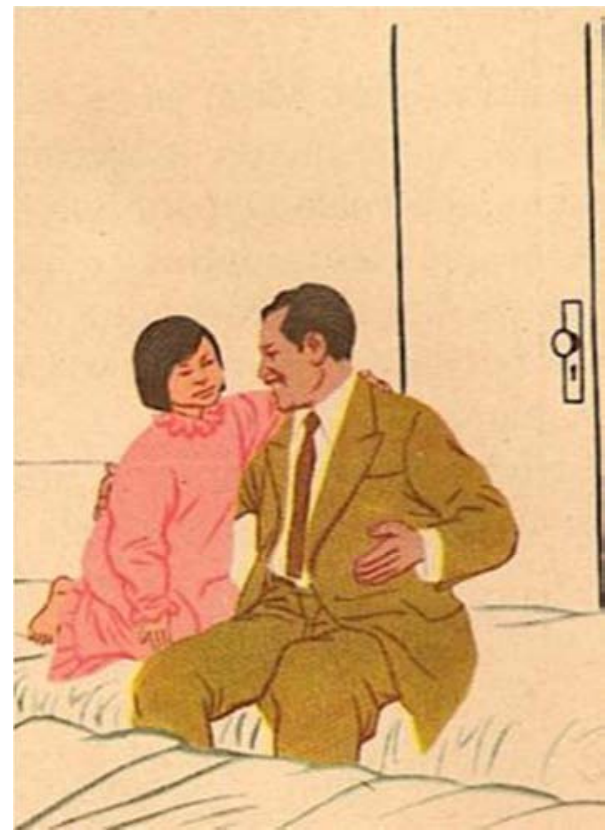

Figure 3. Urban Father-Doctor. My first-grade textbook, 1960, p. 58.

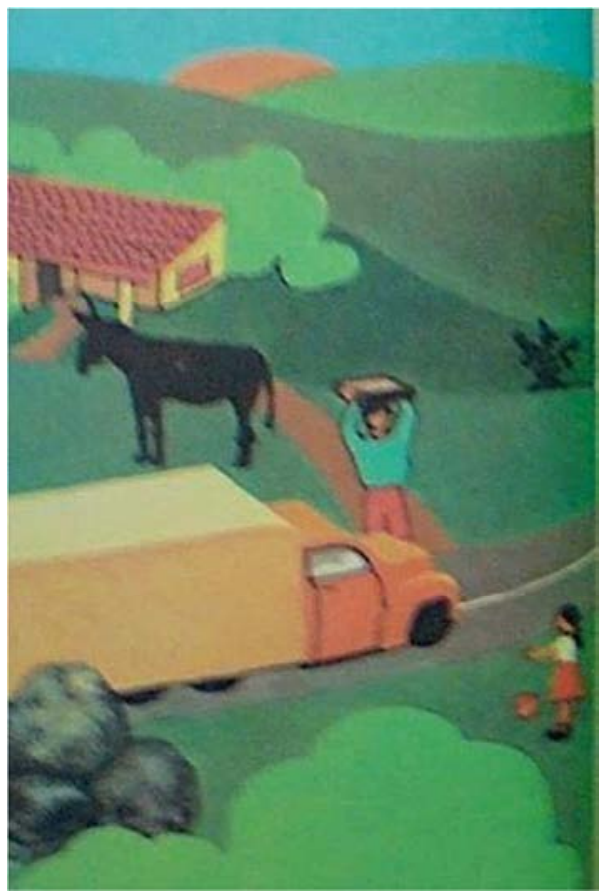

Figure 4. Rural Father-Spanish. First-grade, 1972, p. 24.

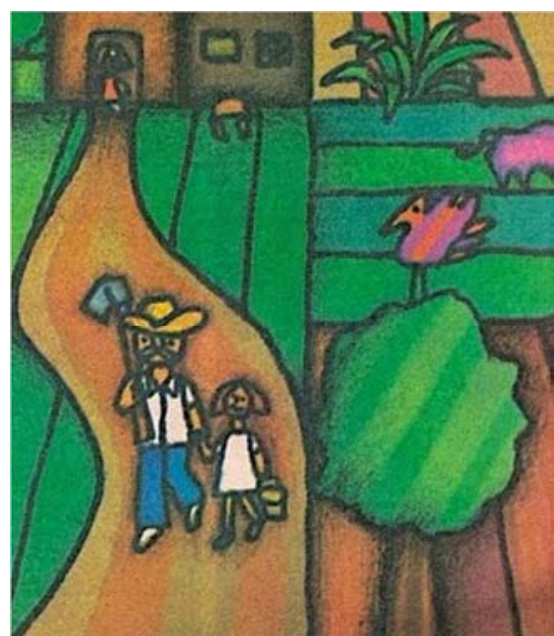

Figure 5. Rural Father-My first-grade textbook, 1988, p. 277.

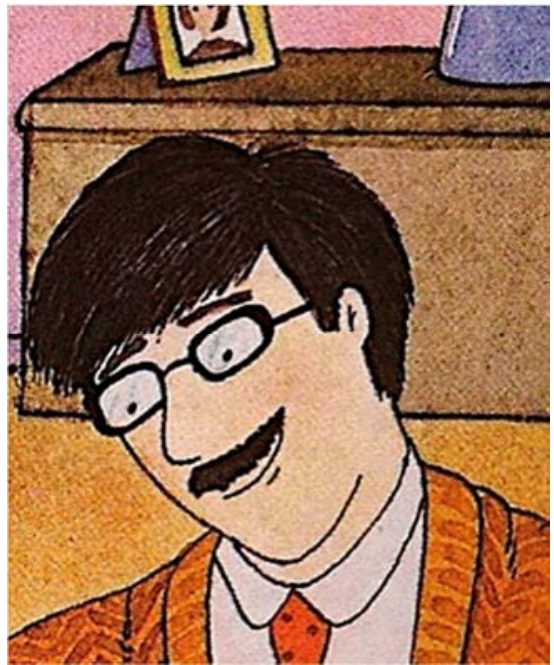

Figure 6. Urban father - Spanish. Second grade. Readings, 1998, p. 67.

Regardless of their occupation, men hold positions of greater importance and responsibility than women, even when they work in the same place or institution; for example, in the health sector, men are doctors and women are nurses. Although, in recent years, there has been a gender discourse and actions in favor of equal job opportunities, as well as a significant participation of women in all areas, the images of Mexican textbooks reviewed continue to illustrate a strong gender division in the jobs the personages fulfil. In this traditional vision of the feminine and masculine activities, men occupy the position of more prestige and authority.

According to Fernández the male Mexican has a proven genealogy in the power figures throughout history, which would suffice to list: the warlords and the indigenous ruling castes, the conquerors, the encomenderos, the colonizers, the organization and all the representatives of the Catholic Church, the gachupines, the criollos, the caciques (also the Indians caciques), the landlords, the foremen, the organization and all the representatives of the army, the class of economic and political power and patriarchs, among the most conspicuous. This permanent male authoritarian presence is the testimony to a legacy and an axis of 
transmission that cannot be denied, mainly because it still prevails in the majority social nerve $[19]^{3}$.

Due to these gender customs, textbooks discourse preserves the traditional male concept, although the illustrations complement it with a committed father in charge of the home and the children's education. So, especially in terms of everyday actions and obligations, masculine characters of official textbooks have always been portrayed as important and active members of the social economic system; only in the family context the role as father is emphasized.

\subsection{The Caring Mother}

Like male roles, feminine functions are kept almost the same in all analyzed editions. The characterization of women corresponds to the mother / housewife who takes care of the family and the home. Although, as it has been already established, some illustrations draw the father bathing or putting the children to bed, the mother has the biggest responsibility of the house and the children. For this reason, female figures are usually placed inside or in the immediate vicinity of their homes. Even when they are not portrayed inside the house, women remain linked to the maternal function: the mother is the one who brings the errands, takes the children to school, watches over the children in the park.

Perhaps the main difference between the textbooks representation of the parents is their role in society, when they are not home. While most images of women, inside or outside the house, show a mother taking care of the family; men have other occupations different than just to be a father. In this way, men have a family role as fathers and a social role as productive workers -doctors, peasants, employees, lawyers, policemen-. On the other hand, most of the time, the women's position is just to be a wife and / or a mother in any context or situation. This gender contrast is manifested in many different discursive genres-literature, movies, advertising, music, as shown in the next fragment.

Ibargüengoitia wrote that he once heard a taxi driver claim: "Did you hear the nonsense that one of these women said today? that the "of" in the surname is infamous. Because it denotes property: a lady is "of Mr. So-and-So". Come on! Please! When we all know that the "of" in the surname is the only thing that makes a woman honorable! It is a sign that she has already chosen her life, formed a home and is the mother of a family, within which she can indulge into the

3 El del macho mexicano tiene una acreditada genealogía en las figuras masculinas del poder a lo largo de la historia, que bastaría con enumerar: los señores de la guerra y las castas gobernantes indígenas, los conquistadores, los encomenderos, los colonizadores, la organización y todos los representantes de la Iglesia católica, los gachupines, los criollos, los caciques (también los indios), los terratenientes, los capataces, la organización y todos los representantes del ejército, la clase del poder económico y político y los padres de familia, entre los más conspicuos. Esta permanente presencia autoritaria masculina es testimonio de un legado y un eje de transmisión que no puede ser desconocido, sobre todo porque continúa imperando en el nervio social mayoritario [19].

4 In Mexico, a woman does not take the husband's name after the marriage; but there is a custom of placing unofficially the surname of the man preceded by the preposition "of". For example, María Pérez of Rodríguez. characteristics of her feminine being. Because, no matter how much we want, we cannot change: man is bold, and woman is sublime" $[21]^{5}$.

Due to the difference between female and male roles, the care that parents give to their children is different: the father cares in the sense of protecting and providing; the mother, in the sense of attending. Thus, the mother is frequently shown doing some housework, according to the feminine function (see Figure 7). For this reason, all textbooks of all different edition reviewed include similar images of the mother cooking, serving the children, cleaning and organizing the house. However, it must be noted that, just as the female characters care for the others, women are also cared for and protected during pregnancy, a transcendental moment to become a mother (see Figure 8).

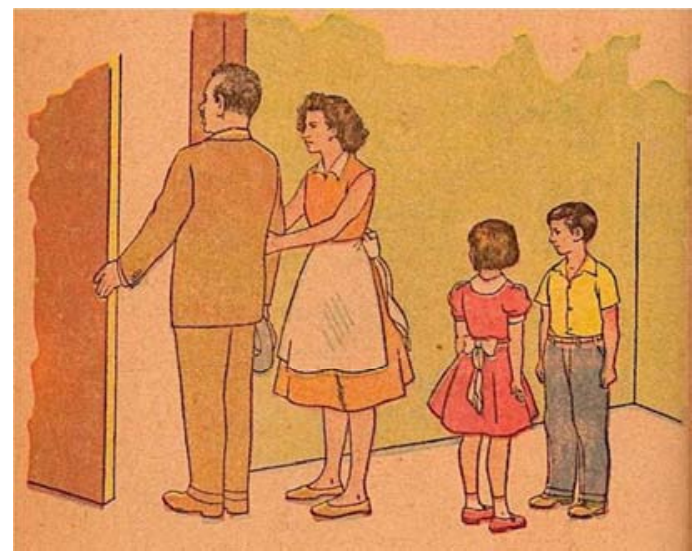

Figure 7. My second-grade textbook, 1960, p. 32.

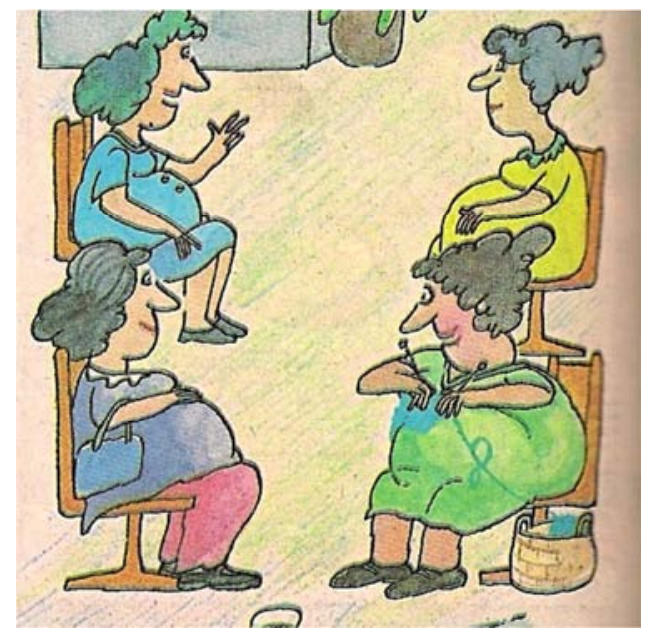

Figure 8. My second-grade textbook, 1988, p. 270.

As observed above, official textbook's father does not

5 ¿Oyó usted la barrabasada que dijo una de esta mujeres hoy?: dizque el "de" en el apellido es infamante. Que porque denota propiedad: una señora es "de Fulano”. ¡Hágame el favor! ¡Cuando todos sabemos que el “de” en el apellido es lo único que hace honrada a una mujer! Es señal de que ya escogió su vida, formó un hogar y es madre de una familia, en el seno de la cual puede dar rienda suelta a las características propias del modo de ser femenino. Porque eso sí, por más que queramos no podemos cambiar: el hombre es aventado y la mujer es sublime" [21]. 
correspond to the primal father; the same thing happens with the mother. The original female predecessor is a dual character, is the Malinche and the Virgen; however, textbooks do not represent this duality, they only illustrate a loving and dedicated mother. Lamas [22] observes that "the myth of the mother is the myth of maternal omnipotence, arising out of unconditional love, absolute self-denial and heroic sacrifice ${ }^{6 "}$. The woman is the one who loves, cares, supports and serves the rest of the family members (see Figures 9, 10 and 11). This undivided delivery to the maternal function is the evidence of the selflessness and sacrifice, that links women to the suffering Mexican mother that only exists for attending and assisting the husband and children.

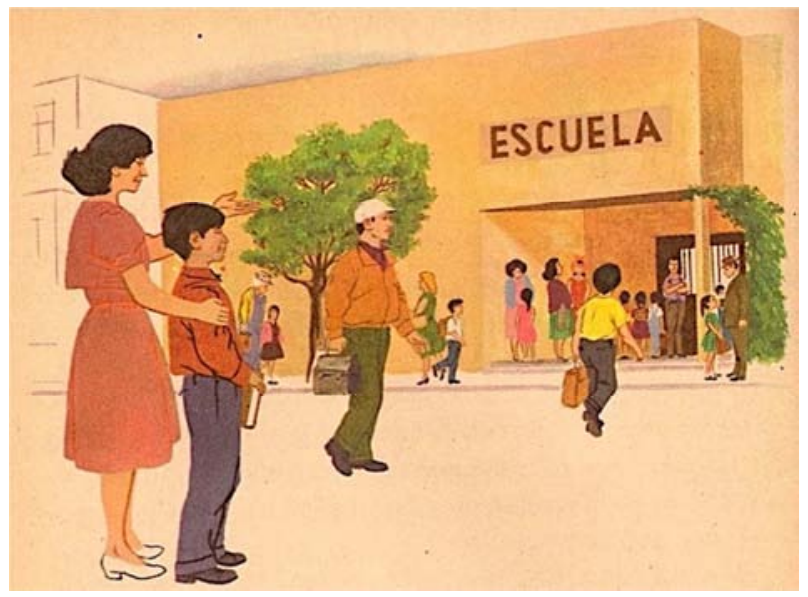

Figure 9. My first-grade textbook, 1963, p. 54.

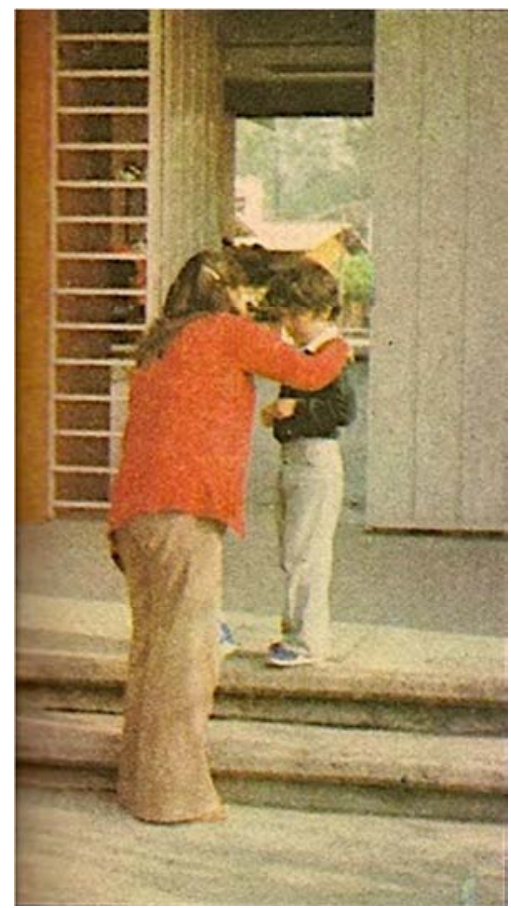

Figure 10. My second-grade textbook, 1988, p. 491.

6 El mito de la madre es el mito de la omnipotencia materna, surgida del amor incondicional, de la abnegación absoluta y del sacrificio heroico [22].

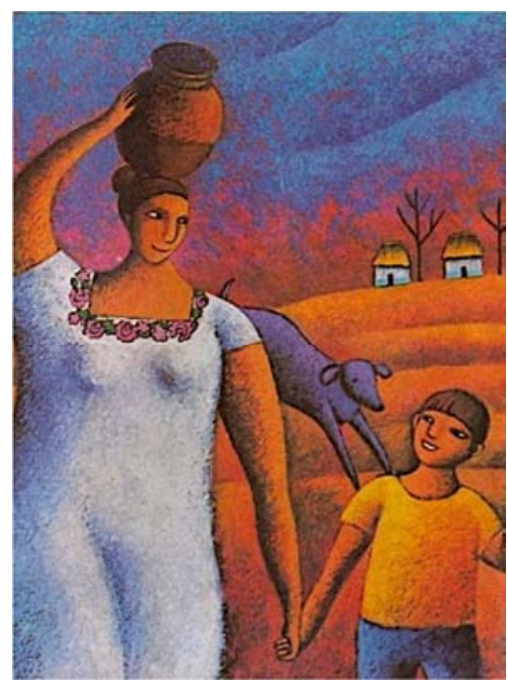

Figure 11. Spanish. Second grade. Readings, 1997, p. 168.

Although women fulfill the role mother most of the time, in some occasions they can also work outside the house. But they cannot choose just any kind of occupation; feminine employment has to be compatible with their gender condition. "Female" jobs usually include two characteristics: first, they are located in closed spaces; second, their services are an extension of their maternal function. Consequently, working women, on textbooks and other various mass media texts, are teachers, maids, seamstresses, nurses or market employees (see Figures 12 and 13).

Pacheco explains that, due to the family's economic situation, many housewives left their homes early to become maids, janitor, seamstresses, ironers, waitresses. That is, to indulge in tasks that they already did, only this time in unsuspected areas. So, their jobs developed to be an extension of their domestic labor, with their usual working tools: plates, broom, stove, tray $[23]^{7}$.

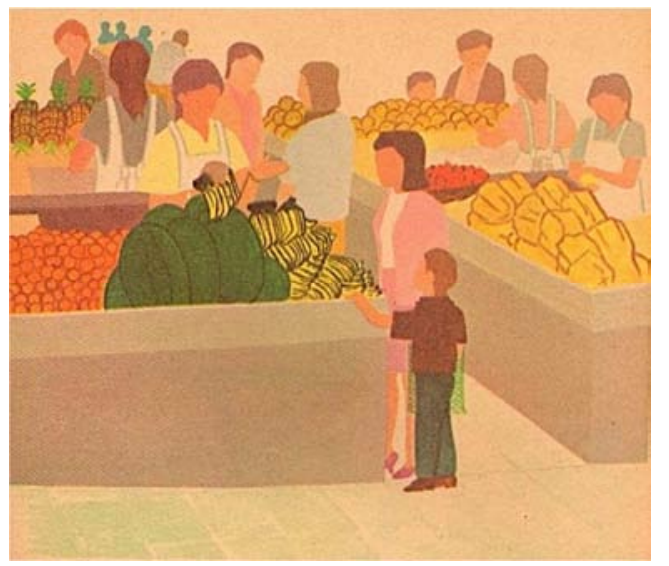

Figure 12. Market employee - Spanish. Second-grade textbook, 1972, p. 2.

\footnotetext{
7 Urgidas por la situación económica familiar, muchas amas de casa abandonaban su domicilio desde temprano para convertirse en sirvientas, afanadoras, costureras, planchadoras, meseras. Es decir, para entregarse a tareas insospechables, entre otras cosas porque las hacían en ámbitos que resultaban una prolongación de los trabajos domésticos, donde, además, sus implementos de trabajo eran los cotidianos: planchas, escoba, estufa, charola [23].
} 


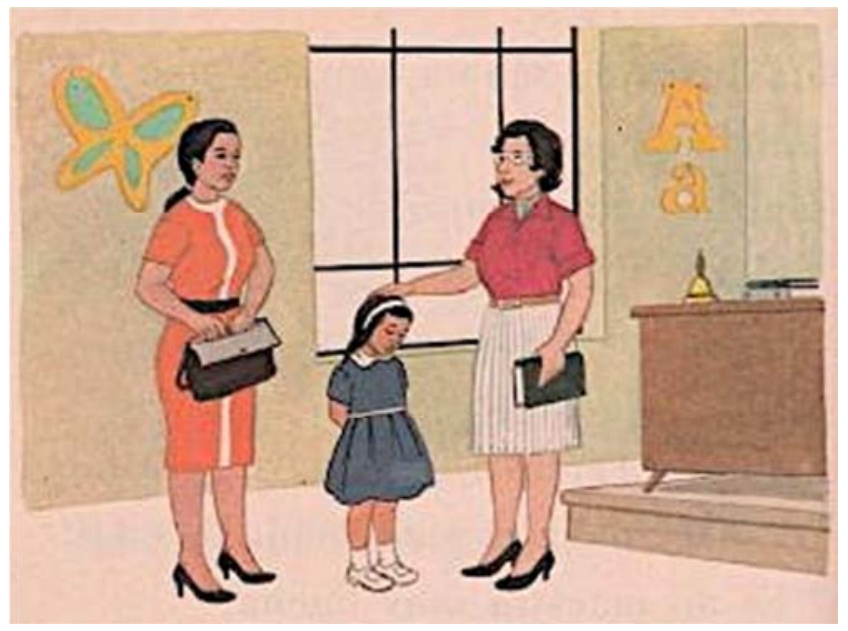

Figure 13. Teacher-My first-grade textbook, 1963, p. 104.

Mier y Terán \& Pederzini [24] observes that, in Mexico, even today, educational opportunities for women are remarkably unequal depending on the place of residence, that is, in rural and semi-urban areas. According to this cultural context, compared to male jobs, textbook's female jobs are simpler. The complexity of masculine work is larger not only because of the physical effort required, but also because of the preparation: professionals are men; women reach, at best, technical positions ${ }^{8}$. It can be assumed that, as the end of the 20th century approached, Mexican official textbooks would show a greater number of female workers, with more equitable jobs or, even, in positions of power. Nevertheless, the images of the 1994 edition still show that women's role is primarily their maternal function; so, the positions of power and important professions continue to be occupied by men.

Even in the fantasy stories included in textbooks, men have a power position and women are mothers. Latapí [25] observes that the hegemony of men over women is one of the characteristics of México's cultural context that hinders an egalitarian education. This way, official educational materials propose the preservation of a structure and a certain social order, promoting certain interpersonal relationships within the institutions, like the family, where Mexicans develop their daily lives.

\subsection{The Children}

The difference of gender positions is more pronounced in adults; children's roles do not manifest such an important separation due to their masculinity or femininity. For this reason, textbooks usually present the figure of children as a whole, regardless of their specific gender. Nonetheless, there are some discrepancies between boys and girls that are shown in very precise opportunities, as commented afterwards.

Children of textbooks' images generally perform two

8 The job of elementary school teacher was a technical position until the change of the curricula in 1984. To date, nursing can be studied as a technical career, although the bachelor's degree in nursing has been accredited since 1968 by the Universidad Nacional Autónoma de México (UNAM - National Autonomous University of Mexico). tasks: they obey their parents and they do their school exercises. Official educational materials display kids' obedience through illustrations of sons and daughters listening attentively to their parents, walking by their side holding hands or, even, worshiping pictures of their father and mother. Children's compliance is also observed in the help they provide to their parents with the housework; therefore, some images show the whole family collaborating to finish household chores. However, these errands are not actually kids' responsibility, but are an aid they give to their parents for the respect and obedience that they owe them.

Just as the father financially supports the family and the mother serves and cares for the husband and kids, the children are committed to attend school and to do their homework. The obligatory nature of school work over household chores is manifested in two ways: because of the topic or the number of textbooks images. As for the subject, you can see illustrations where the mother is shown doing the housewife chores, while children do the homework (see Figures 14 and 15); as for its quantity, it should be noted that the percentage of images with kids helping in the housework, little by little, is reduced in each edition. In this way, textbooks become part of children's infantilization discourses.

The idea of infantilization refers to the historical process by which a growing portion of society would be considered as naturally weak, heteronomous and in need of protection. In this process, childhood was delimited and categorized, whereupon kids were excluded (and eventually also young people) from the world of adults ${ }^{9}$ [26].

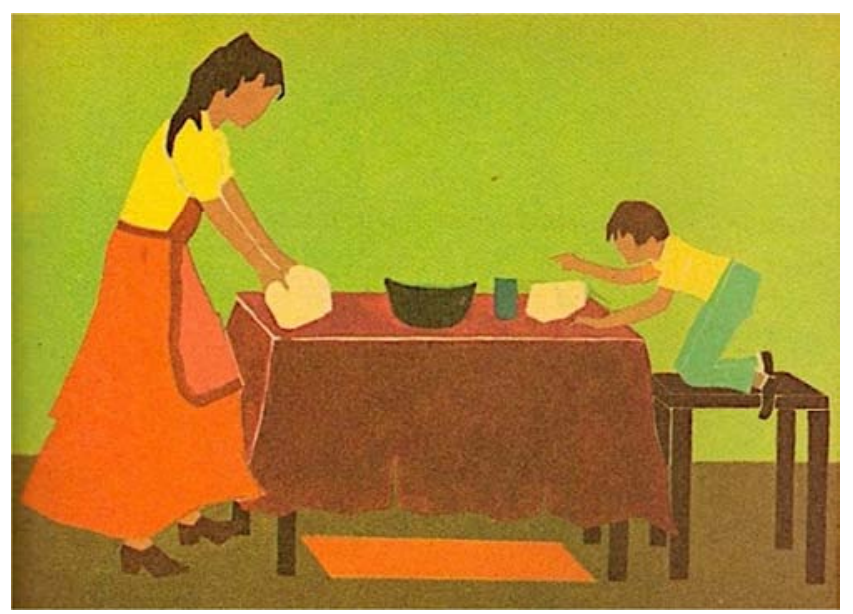

Figure 14. Spanish. Second-grade textbook, 1972, p. 99.

9 La idea de infantilización se refiere al proceso histórico mediante el cual una porción creciente de la sociedad sería considerada como naturalmente débil, heterónoma y necesitada de protección. En dicho proceso la infancia fue delimitada y categorizada, con lo que se logró por un lado excluir al niño (y eventualmente también al joven) del mundo de los adultos [26]. 


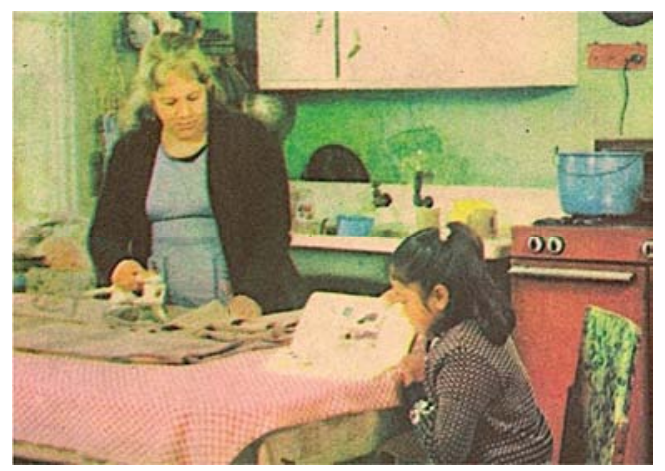

Figure 15. My first-grade textbook, 1988, p. 87.

Although boys and girls have the same role in family and in school, there are certain peculiarities that distinguish fellows and ladies. Children follow the gender guidelines established for adults; this can be observed in the distribution of housework and the games played by sons and daughters. Girls usually assistance with the cleaning or doing some duties in the kitchen; boys' errands consist in helping their father with the maintenance of the house or also cleaning. It should be mentioned that some illustrations display boys helping their mother with, what can be considered, feminine tasks such as cooking; though, girls never are shown assisting their fathers. This way, textbooks draw a line between female and male task, and women are not allowed to trespass the work aimed at men.

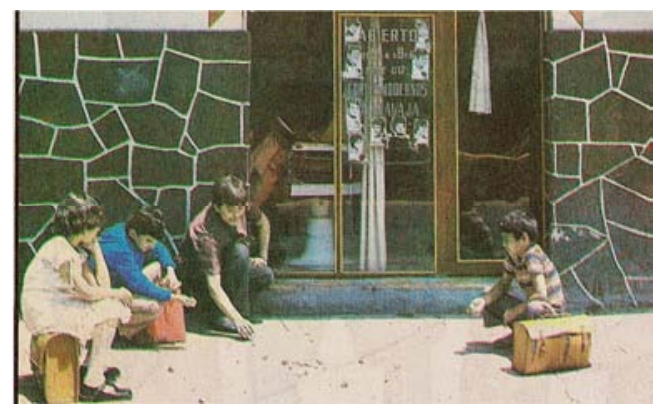

Figure 16. My second-grade textbook, 1988, p. 150.

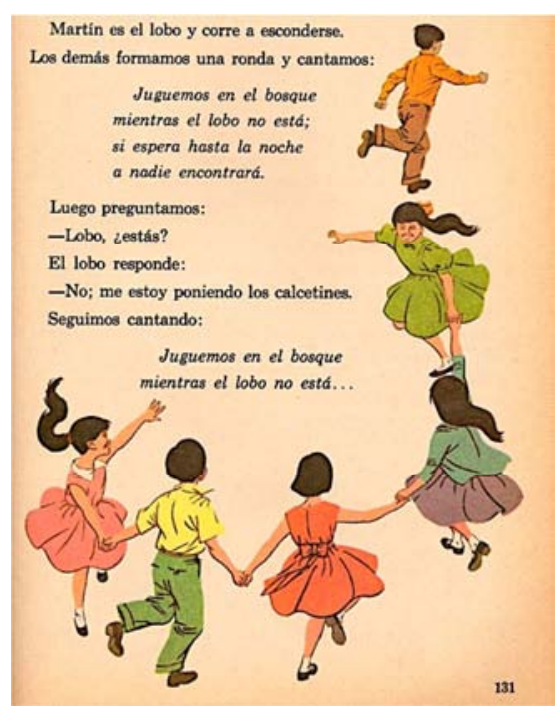

Figure 17. My second-grade textbook, 1963, p. 131.
About the gender division of amusement, images reveal the existence of games for women, for men and for both. Although many family representations refer to recreations where all members - sons and daughters- participate, the games divergence regards a traditional posture of masculine and feminine entertainment: girls join in playground games, have dolls and play hopscotch; boys enjoy soccer, marbles and strollers.

Even though girls can appear in some illustrations in the context of male games, they are only spectators (see Figure 16). The opposite occurs with boys, for whom is acceptable to participate in "female" games (see Figure 17). Thereby, through the representation of games and housework, textbooks' images join the discourses that establish a traditional separation of the gender roles. From this perspective, while men can enter the feminine space, women must stay out of the masculine fields.

\section{Conclusions}

Textbooks intend the conformation of a national culture, due to which they present a homogenous Mexican society; however, this does not imply equality in all characters or groups. Social disparity among the average Mexicans on textbooks' images may be the result of their socioeconomic status, the space where they live (city or rural area) and their gender situation. Gender inequity is built on a traditional division of female and male roles, that is preserved throughout all the editions corresponding to the first fifty years of the official educational materials.

Analyzed images represent men as the hegemonic personages of the Mexican state system. Due to their importance to maintain social order, male characters have two main functions: as head of the family, they must protect and provide for their homes; as active elements of the socioeconomic system, they work in different trades or institutions according to their abilities and opportunities. By contrast, women are mostly affectionate mothers and housewives economically dependent on their husbands; so, their main occupation is to serve their families and fix the house. The few working female characters have jobs that allow them to perform traditionally feminine functions: either caring for children or sick people (teachers and nurses), either cleaning the house (maids).

Despite the fact that over time, women have played different positions in the most diverse areas, traditional gender division of female and male roles has been maintained since the 1960 editions to those of the first decade of the 21 st century. In addition, the images reviewed still indicate that the highest-paying employments, that require more training and have greater prestige, are occupied by male protagonists. Regardless the increasingly number of homes where the mother has a job outside their homes, textbooks still show women as housewives and men as providing fathers. 


\section{References}

[1] Giddens, A. (2001). Modernity and Self-Identity: Self and Society in the Late Modern Age. Cambridge: Polity Press.

[2] Barriga, R. (1999). "Cuatro décadas de enseñanza del español en México" ("Four decades of teaching Spanish in Mexico"). Español actual: Revista de español vivo, 71: 83-100.

[3] Meza, A. (2012). "Los Libros de texto" (“Textbooks"). In P. Latapí, Un siglo de educación en México. Vol. II., 46-58. México: CONACULTA/FCE.

[4] Corona, S. (2015). La asignatura ciudadana en las cuatro grandes reformas del LTG en México (1959-2010) [The civic subject in the four major reforms of the LTG in Mexico (19592010)]. México: Siglo XXI Editores.

[5] Flores Andrade, A. (2017). "La reforma educativa de México y su Nuevo Modelo Educativo" (The educational reform of Mexico and its New Educational Model). Revista Legislativa de Estudios Sociales y de Opinión Pública, 10 (19): 97-129.

[6] Gutiérrez, N. (2012). Mitos nacionalistas e identidades étnicas: los intelectuales indígenas en el Estado mexicano (Nationalist myths and ethnic identities: indigenous intellectuals in the Mexican state). México: CONACULTA / Instituto de Investigaciones Sociales de la UNAM / Plaza y Valdés.

[7] Burke, P. (2014). Eyewitnessing. The Uses of Images as Historical Evidence. London: Reaktion Books.

[8] Sartori, G. (2018). Homo videns. La sociedad teledirigida (Homo Videns: The teledirected society). Barcenola: Debolsillo: 84.

[9] Gombrich, E. H. (2018). The image and the eye: further studies in the psychology of pictorial representation. London: Phaidon Press Limited.

[10] Barthes R. (2000). Image, Music, Text. London: Fontana Press: 17.

[11] Goffman, E. (2005). Interaction Ritual: Essays in Face to Face Behavior. New Brunswick / London: Aldine Transaction.

[12] Corona, S. (2006). "La fotografía indígena en los rituales de la interacción social" (The indigenous photography in the rituals of social interaction). Comunicación y Sociedad, 006: 91-104.

[13] Barthes, R. (2010). A Lover's Discourse: Fragments. New York: Hill \& Wang

[14] Cruder, G. (2013). La educación de la mirada. Sobre los sentidos de la imagen en los libros de texto (The education of the look. About the images' meanings in textbooks). Buenos Aires: Stella / La Crujía.

[15] Lindig Cisneros, E. (2016). "Violencias culturales. La figura de la mujer mexicana en El laberinto de la soledad"(Cultural violences. The figure of the Mexican woman in The Labyrinth of Solitude). In A. Villegas Contreras, N. Talavera Baby, R. Monroy Áivarez, Figuras del discurso, exclusión, filosofía y política, 181-194. México: Bonilla Artigas Editores / Universidad Autónoma del Estado de Morelos.

[16] Ramos, S. (2013). El perfil del hombre y la cultura en México (Profile of Man and Culture in Mexico). México: Espasa Calpe.

[17] Paz, O. (2015). El Laberinto De La Soledad. Postdata, Vuelta a "El laberinto de la soledad" (The Labyrinth of Solitude, Postdata, Return to "The Labyrinth of Solitude"). México: Fondo de Cultura Económica.

[18] Bartra, R. (2015). La jaula de la melancolía: Identidad y metamorfosis del mexicano (The cage of melancholy: Identity and metamorphosis in the Mexican character). México: Debolsillo.

[19] Fernández, M. (2015). "El macho y el machismo" ("The male and macho"). En E. Florescano, Mitos mexicanos, 231-238. México: Taurus: 237 and 234-235

[20] Ortega Villa et al. (2016). "Rasgos socioculturales de los jóvenes en México: bienestar, cultura y política" ("Sociocultural characteristics of young people in Mexico: wellbeing, culture, and politics"), Estudios sociales, 24-25 (47). http://www.scielo.org.mx/scielo.php?script=sci_arttext\&pid=S 0188-45572016000100282

[21] Ibargüengoitia, J. (2015). Instrucciones para vivir en México (Instructions to live in Mexico). México: Joaquín Mortiz: 285286.

[22] Lamas, M. (2015). “¿Madrecita Santa?” ("Holy Mommy?"). In E. Florescano, Mitos mexicanos, 223-229. México: Taurus: 225 .

[23] Pacheco, C. (2015). "Las secretarias" ("The secretaries"). In E. Florescano, Mitos mexicanos, 387-391. México: Taurus: 388.

[24] Mier y Terán, M. \& Pederzini, C. (2018). "Cambio sociodemográfico y desigualdades educativas" ("Sociodemographic change and educational inequalities"). In Alberto Arnaut \& Silvia Giorguli, Los grandes problemas de México. Vol. VII, 623-657. México: El Colegio de México.

[25] Latapí, P. (2015). "Planteamientos educativos en valores y derechos humanos" (Educational approaches about values and human rights), In Felipe Martínez Rizo, Pablo Latapí Sarre en la UAA, 59-64. Aguascalientes: Universidad Autónoma de Aguascalientes

[26] Alcubierre Moya, B. (2016). "La infantilización del niño" (The infantilization of the child). In A. Villegas Contreras, N. Talavera Baby, R. Monroy Áivarez, Figuras del discurso, exclusión, filosofía y política, 317-342. México: Bonilla Artigas Editores / Universidad Autónoma del Estado de Morelos. 